IZA DP No. 6826

The Labor Market Consequences of Adverse Financial Shocks

Tito Boeri

Pietro Garibaldi

Espen R. Moen

August 2012 


\title{
The Labor Market Consequences of Adverse Financial Shocks
}

\author{
Tito Boeri \\ Bocconi University, \\ fRDB and IZA \\ Pietro Garibaldi \\ University of Torino, \\ Collegio Carlo Alberto and IZA \\ Espen R. Moen \\ Norwegian School of Management
}

Discussion Paper No. 6826

August 2012

\author{
IZA \\ P.O. Box 7240 \\ 53072 Bonn \\ Germany \\ Phone: +49-228-3894-0 \\ Fax: +49-228-3894-180 \\ E-mail: iza@iza.org
}

\begin{abstract}
Any opinions expressed here are those of the author(s) and not those of IZA. Research published in this series may include views on policy, but the institute itself takes no institutional policy positions.

The Institute for the Study of Labor (IZA) in Bonn is a local and virtual international research center and a place of communication between science, politics and business. IZA is an independent nonprofit organization supported by Deutsche Post Foundation. The center is associated with the University of Bonn and offers a stimulating research environment through its international network, workshops and conferences, data service, project support, research visits and doctoral program. IZA engages in (i) original and internationally competitive research in all fields of labor economics, (ii) development of policy concepts, and (iii) dissemination of research results and concepts to the interested public.
\end{abstract}

IZA Discussion Papers often represent preliminary work and are circulated to encourage discussion. Citation of such a paper should account for its provisional character. A revised version may be available directly from the author. 


\section{ABSTRACT}

\section{The Labor Market Consequences of Adverse Financial Shocks}

The recent financial crises, alongside a dramatic rise in unemployment on both sides of the Atlantic, suggest that financial shocks do translate into the labor markets. In this paper we first document that financial recessions amplify labor market volatility and Okun's elasticity over the business cycle. Second, we highlight a key mechanism linking financial shocks to job destruction, presenting and solving a simple model of labor market search and endogenous finance. While finance increases job creation and net output in normal times, it also augments their aggregate response in the aftermath of a financial shock. Third, we present evidence coherent with the idea that more leveraged sectors experience larger employment volatility during financial recessions. Theoretically, the job destruction effect of finance works as follows. Leveraged firms may find themselves in a position in which their liquidity is suddenly called back by the lender. This has direct consequences on a firm ability to run and manage existing jobs. As a result, firms may be obliged to shut down part of their operations and destroy existing jobs. We argue that with well-developed capital markets, firms will have an incentive to rely more on liquidity, and in normal times deep capital markets lead to tight labor markets. After an adverse liquidity shock, firms that rely much on liquidity are hit disproportionally hard. This may explain why the unemployment rate in the US during the Great Recession increased more than in European countries experiencing larger output losses. Empirically, the paper uses a variety of datasets to test the implications of the model. At first we identify crises that, just like in the model, caused a sudden reduction of liquidity to firms. Next we draw on sector-level data on employment and leverage in a number of OECD countries at quarterly frequencies to assess whether highly leveraged equilibria originate more employment adjustment under financial recessions. We find that highly leveraged sectors and periods are associated with higher employment- to-output elasticities during banking crises and this effect explains the observation of higher Okun's elasticities during financial recessions. We also argue that the effect of leverage on employment adjustment can be interpreted as a causal effect, if our identification assumptions are considered plausible. All this amounts essentially for a test of the labor demand channel of adjustment.

JEL Classification: G1, J2, J6

Keywords: financial shocks, matching, Okun's elasticities

Corresponding author:

Tito Boeri

Department of Economics

Università Bocconi

via Roentgen 1

20136 Milano

Italy

E-mail: tito.boeri@unibocconi.it 


\section{Introduction}

In the aftermath of the financial crisis, unemployment in the U.S almost doubled from peak to trough, within a few quarters. Its short-run dynamics displayed remarkably larger Okun's elasticity than in previous recessions. US unemployment is now declining at a very low pace, denoting more persistence than in previous recoveries, including the jobless recoveries of the last two decades. Unemployment in Europe has been consistently lower than in the US throughout the Great Recession (Figure 1), although the aggregate EU figures conceal large cross-country heterogeneity in the responsiveness of unemployment to output changes.

Some of these differences in response across the two sides of the Atlantic are arguably linked to the different labor market institutions. According to an institutional approach and economic analysis fashionable in the mid nineties, one could argue that strict employment protection legislation (EPL) in Europe is the smoking gun. High costs of dismissals, according to this perspective, are associated with lower labor market volatility. However, the countries with the strictest EPL, like Spain, this time experienced the largest increase in unemployment. The fact of the matter is that European labor markets are today much more flexible on average than a couple of decades ago, and are characterized by a dual structure. Such a dual structure, with a flexible temporary fringe alongside a rigid stock of regular contracts, increased labor market response to adverse business conditions precisely in those countries displaying the strictest employment protection provisions for regular contracts.

One should therefore go beyond labor market institutions to understand these asymmetric and largely unprecedented developments. A key factor behind the response of the labor market to the current recession is likely to be in the nature of the shocks that led to the Great Recession. In particular, one should look at the financial markets where the crisis developed and became global in the aftermath of the Lehman bankruptcy in the Fall of 2008. Financial markets and the banking sector experienced a credit crunch well into the 2009. Such a credit crunch has been documented by several authors and took place in both Europe and the U.S. This global credit crunch is likely to have been playing a key role in labor market adjustment during the downturn and in the recovery.

With respect to the financial sector, one of the key differences between the two sides of the Atlantic is the degree of financial deepening. A simple empirical measure to account for this difference is the stock market capitalization over GDP. While the size of the financial shocks, measured in terms of losses of stock market capitalization, appear very similar in terms of timing and size, what is striking is the fact that the level of financial deepening is indeed very different: credit to the private sector as a share of GDP has been consistently larger in the US than in Europe in the last 50 years and the gap across the two sides of the Atlatic actually increased over time (Figure 2). Similarly, in the US stock market capitalization is larger than in the EU: at the outset of the Great Recession it was some 100 percent of GDP, while the same ratio in Europe was about 75 percent (Figure 3).

We study theoretically and empirically the basic links and transmission mechanisms between the shocks to the financial markets and the labor market. The questions of this line of research are the following. How does a credit crunch translate into job destruction and larger unemployment? Is financial deepening

- larger as we have seen in the U.S. than in Europe - responsible for the acceleration and increase of the unemployment to output response in the U.S. to the financial shocks of 2008 and 2009? How does this explanation cope with the sluggish dynamics of US unemployment during the recovery? And how about differences in Okun's elasticities across sectors?

The paper focuses on the job destruction effect of finance. Leveraged firms may find themselves in a position in which their liquidity is suddenly called back by the lender. Such a sudden call back in liquidity has direct consequences on a firm ability to run and manage existing jobs. As a result, firms may be obliged to shut down part of their operations and destroy existing jobs. In this sense, the job destruction effect of the credit crunch is essentially a labor demand driven channel of adjustment.

We argue that with deep capital markets, firms will have an incentive to rely more on liquidity, and in normal times deep capital markets lead to tight labor markets. After an adverse liquidity shock, firms that rely much on liquidity, are hit disproportionally hard. This may explain why the unemployment rate in the US has increased relatively more compared with many European countries in the aftermath of the Great Recession. 
Figure 1: Unemployment in the U.S. and Europe

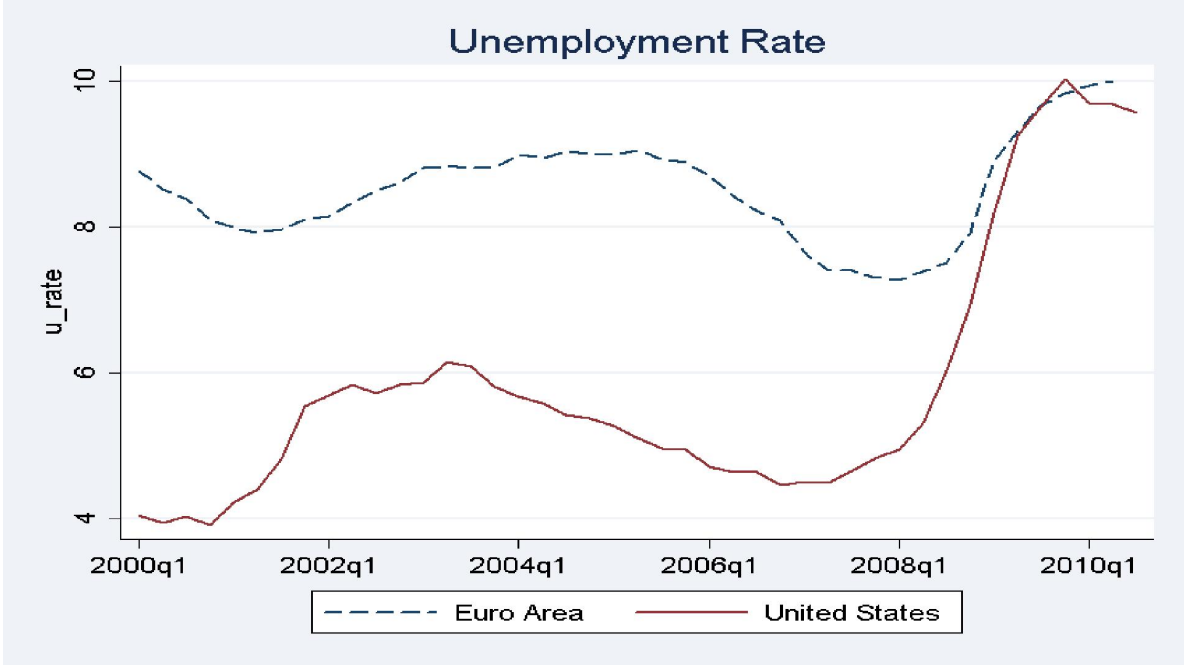

Empirically, the paper uses a variety of datasets on both the U.S. and Europe to ask whether it is possible to identify the effects outlined by the model. We draw on two-digits sector-level data on employment and financial market conditions over a large number of OECD countries at quarterly frequencies. We take the US as a benchmark and find that sectors with significantly lower leverage ratios vis-à-vis the same sector in the US (part of the cross-industry differences in leverage ratios can be related to the specific technological or product-demand characteristics of the different sectors) experienced lower employment-to-output elasticities. This amounts essentially for a test of the labor demand channel of adjustment.

The structure of the paper is as follows. We first review the basic facts on unemployment dynamics, financial shocks and Okun's elasticity over the business cycle. Second, we highlight the job destruction effect of finance in a simple search model with endogenous finance. We show that in an economy more dependent on credit firms will have an incentive to rely more on liquidity, and in normal times deep capital markets lead to tight labor markets. In a high credit equilibrium, after an adverse liquidity shock, firms that rely much on liquidity, are hit disproportionally hard and experience a larger increase in unemployment. Third, we go back to the data and find evidence that more leveraged sectors experience more volatility in the midst of a financial recession.

\section{Is the Labour Market More Volatile During Financial Reces- sions?}

In order to evaluate whether financial recession are associated to more labor market volatility, we looked at the employment-to-output elasticity during financial and non-financial recessions. We proceeded in two steps. At first, we estimated time varying employment-Okun's betas rolling regressions, carried out over a 5 years, 20 quarters, window, for the G7 from the simple static specification

$$
\Delta e_{t}=c-\beta \Delta y_{t}
$$

where $\Delta e_{t}$ is the change in the employment rate and $\Delta y_{t}$ is real output growth, $\beta=\frac{\Delta e_{t}}{\Delta y_{t}}$ is the elasticity of employment to output or the employment content of gdp growth. We run these regressions separately in each country also in light of the unbalanced nature of our panel. Next, we compared the average elasticity during financial as well as non-financial crises, using Reinhart and Rogoff (2008) taxonomy of the crises. In doing so, we take a 20 quarters window beginning with each recession. 
Our results are summarized in Table 2.

As we can see, they indicate that during financial recessions there is more volatility of employment conditioning on output than at normal times. Okun's beta are also larger than during ordinary recessions and the difference is always statistically significant: financial recessions seem to involve a larger responsiveness of employment to output changes.

This is consistent with Bernanke and Gertler (1989), who found that more leveraged firms suffer more under a credit crunch, and more broadly with the literature suggesting that firms' balance sheets amplify business fluctuations.

To our knowledge, there is no model of labor-finance interactions framing this fact. We will now develop a simple model capable of explaining this feature of financial recessions and yielding further testable implications on labor-finance interactions.

\section{A Model of Search and Finance}

In this section, we present and solve a simple model of labor and finance that can show that an economy more dependent on finance is i) more productive on average but, at the same time, ii) more vulnerable to aggregate financial shocks. The simple model can quickly rationalize why unemployment fluctuates more in an economy which relies more on credit to the private sector.

\subsection{The Environment}

Production requires an entrepreneur, a worker and, potentially, finance or credit. In other words, finance or credit (used interchangeably) is akin to an input in production. All agents are risk neutral and discount the future at rate $r$ Entrepreneurs must choose ex-ante the finance intensity of their production. We call the finance intensity, the leverage of the firm and we indicate it with $l$

While we assume that finance is readily available at the time of job creation, it can be suddenly pulled back to the firm as a result of an idiosyncratic shock $\lambda_{o}$ Conditional upon a financial shock, production can still continue without credit and we say that a firm in this condition is in financial distress

Figure 2: Credit to the private sector in US and Europe

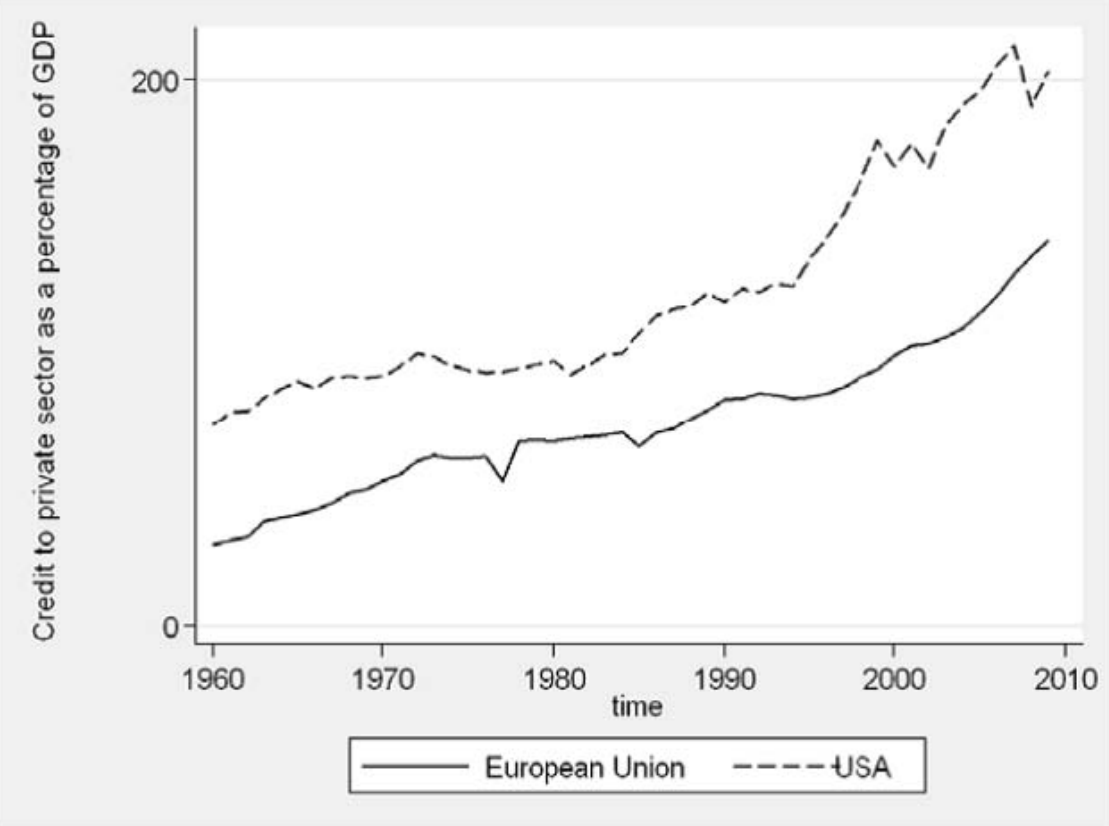


Figure 3: Stock market capitalization over GDP: US vs. Europe

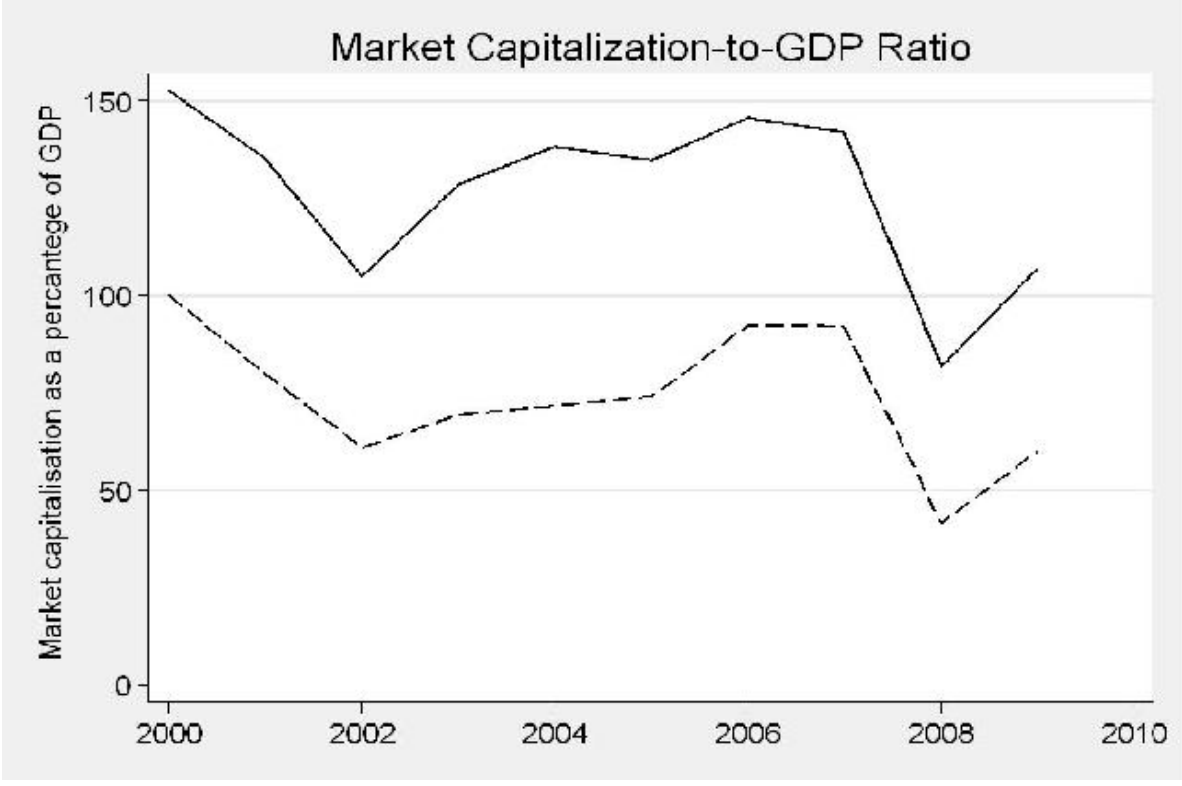

Firms in financial distress can obtain credit back at an exogenous rate $\lambda_{1}$. Formally, the production level $y$ can be written as

$$
y(l)=\left\{\begin{array}{cc}
y(l)=\Delta+l^{\alpha} & \text { if finance is available } \\
y^{d}(l)=\Delta & \text { if the firm is in financial distress }
\end{array}\right.
$$

Where the superscript $d$ refers to the financial distress function. The previous conditions suggest that more leverage increases production in normal times, but it reduces production during financial distress. This basic technological trade off of finance assumed above is consistent with a large body of theoretical literature on liquidity (Holmostron and Tirole, 2011). The cost function $c(l)$ is proportional to leverage and we simply assume that

$$
c(l)=\rho l
$$

where $\rho$ is the marginal cost of leverage and it will play an important role in characterizing different outcomes of the model. Figure 4 describes the relationship between output and leverage.

The labor market is imperfect and is characterized by a standard equilibrium search unemployment model. Entrepreneurs post vacancies and search for workers. Search is random and the meeting between entrepreneurs and workers is described by a traditional matching function $x(u, v)$ where $u$ is the unemployment rate and $v$ is the stock of vacancies also normalized by the labor force. We follow the traditional matching literature and assume that $\theta=\frac{v}{u}$ denotes market tightness while $q(\theta)$ is the firm arrival rate while $\theta q(\theta)$ is the worker meeting rate of vacancies.

Wages are the outcome of Nash Bargaining between workers and firms. We assume that workers obtain a fraction $\beta$ of the total surplus. Entrepreneurs post vacancies at a marginal cost $c$ and there is free entry of firms. Jobs are exogenously destroyed at rate $s$.

With respect to a purely standard search unemployment model, the key novel economic decisions of the model are the job destruction decision conditional on a financial shock $\lambda_{0}$, and the choice of the optimal leverage.

\subsection{Value Functions, Stocks and Equilibrium Definition}

Conditional on leverage $l$, the value of a vacancy $V(l)$ reads

$$
r V(l)=-c+q(\theta)[J(l)-V(l)]
$$


Table 1: Okun's betas (Employment to Output)

\begin{tabular}{lcccc}
\hline \hline & Overall & $\begin{array}{c}\text { During } \\
\text { Financial } \\
\text { Crises (RR) }\end{array}$ & $\begin{array}{c}\text { During } \\
\text { Other } \\
\text { Crises }\end{array}$ & $\begin{array}{c}\text { p-value of } \\
\text { difference }\end{array}$ \\
\hline Australia & 0.170 & 0.403 & 0.136 & $0.052^{*}$ \\
Canada & -0.490 & & 0.659 & $0.041^{* *}$ \\
Finland & 0.183 & 0.288 & 0.175 & \\
France & 0.166 & & 0.138 & \\
Germany & 0.093 & & 0.123 & $0.00^{* * *}$ \\
Italy & 0.115 & 0.374 & 0.025 & \\
Netherlands & 0.081 & 0.120 & & \\
Norway & 0.049 & & 0.028 & \\
Portugal & 0.112 & & 0.137 & \\
Spain & 0.213 & & 0.853 & \\
Sweden & -0.031 & & 0.092 & \\
United Kingdom & 0.144 & 0.283 & & \\
United States & 0.220 & 0.146 & 0.237 & $0.078^{*}$ \\
\hline \hline
\end{tabular}

Figure 4: Output and leverage

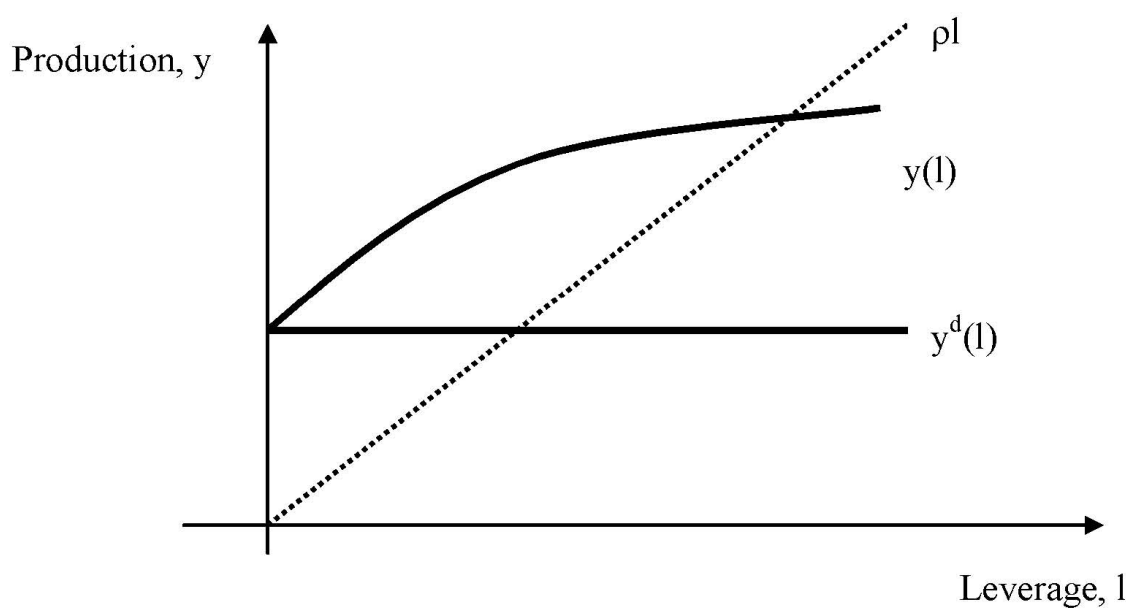


where $J(l)$ is the value of production when finance is available. The value of production is

$$
r J(l)=\Delta+l^{\alpha}-\rho l-w(l)+\lambda_{o}\left\{\operatorname{Max}\left[J^{d}(l) ; V(l)\right]-J(l)\right\}+s[V(l)-J(l)]
$$

where $\Delta+l^{\alpha}-\rho l-w(l)$ are simply net operational profits while the max operator conditional on a finance shock is the key decision of the entrepreneurs, involving the trade-off between operating in distress at value $J^{d}$ or destroying the job and getting the value of a vacancy $V(l)$. In what follows we let the max condition be the optimal job destruction decision so that we can write

$$
\operatorname{Max}\left[J^{d}(l) ; V(l)\right] \quad \text { OPTIMAL JOB DESTRUCTION }
$$

The value of the firm in financial distress reads

$$
r J^{d}(l)=\Delta-w^{d}(l)-\rho l+\lambda_{1}\left\{J(l)-J^{d}(l)\right\}+s\left[V(l)-J^{d}(l)\right]
$$

The corresponding value functions for the workers are readily obtained. If we let $W(l)$ be the value of a job to a worker in normal conditions and $W^{d}(l)$ the value in distress, the value functions read

$$
r W(l)=w(l)+\lambda_{o}\left\{\operatorname{Max}\left[W^{d}(l) ; U\right]-W(l)\right\}+s[U-W(l)]
$$

and

$$
r W^{d}(l)=w(l)+\lambda_{1}\left[W(l)-W^{d}(l)\right]+s\left[U-W^{d}(l)\right]
$$

respectively.

The value of unemployment is also standard. Workers search for vacant jobs and obtain an unemployment income equal to $b$.

$$
r U=b+\theta q(\theta)[W(l)-U]
$$

Wages are set by Nash bargaining and workers obtain a fraction $\beta$ of the total surplus from the job. As is standard in the literature, the wages can be set as

$$
W^{i}(l)-U=\beta\left[J^{i}(l)+W^{i}(l)-V(l)-U\right] \quad \text { WAGE DETERMINATION }
$$

where the expression in square brackets in the right-hand-side is the surplus from the job and the superscript $i$ is equal to $d$ when the job is financially distressed. The right-hand-side is the surplus from the job

$$
\begin{aligned}
S^{i}(l) & =J^{i}(l)+W^{i}(l)-V(l)-U \\
W^{i}(l)-U & =\beta S^{i}(l) ; \quad J^{i}(l)=(1-\beta) S^{i}(l)
\end{aligned}
$$

As is standard in the matching literature with endogenous separations, job destruction takes place when the surplus from the job is zero and there is full agreement between firms and workers on the job destruction condition. Separations are indeed jointly privately efficient.

Free entry of the entrepreneur in the financial market implies that $V(l)=0$ so that for the chosen degree of leverage, the value of a vacancy is zero

$$
V(l)=0 \Longrightarrow J(l)=\frac{c}{q(\theta)} \quad \text { JOB CREATION }
$$

The optimal leverage $l^{*}$ is chosen by the entrepreneur before entering the market and is set so as to maximize the value of a vacancy. In other words

$$
\begin{aligned}
& l^{*}=\arg \max _{l} V(l) \\
& l^{*}=\arg \max _{l} \frac{-c+q(\theta) J^{h}(l)}{r+q(\theta)} \quad \text { OPTIMAL LEVERAGE }
\end{aligned}
$$


In steady state, unemployment inflows are equal to unemployment outflows. Job creation is given by $\theta q(\theta) u$ while job destruction is exogenously given by the separation rate plus the financial shock $\lambda_{o}$ conditional on the optimal job destruction condition of (1). This suggests that the balance flow condition is

$$
\theta q(\theta) u=\left[s+\Phi \lambda_{0}\right] u
$$

where $\Phi$ is an indicator function that takes the value 1 when $J^{d}(l)<0$. The equilibrium unemployment rate is then

$$
u=\frac{s+\Phi \lambda_{0}}{s+\Phi \lambda_{0}+\theta q(\theta)} \quad \text { EQUILIBRIUM UNEMPLOYMENT }
$$

Definition 1 The equilibrium is a set of value functions $\left[J(l), J^{d}(l), V(l), W(l), W^{d}(l), U.\right]$, unemployment stock [u], market tightness $\theta$ and leverage l satisfying i) Optimal Job Destruction (equation 1, ii) Job Creation (equation 3) iii) Wage determination (equation 2)iv) Optimal Leverage (equation 4) v) Equilibrium Unemployment (equation 5)

\subsection{Solving the Model}

To solve the model we need to obtain the value functions in terms of the surplus $S(l)$. Since $V(l)=0$ at the optimal leverage, adding the value functions for firms and workers and subtracting $r U$, after using the wage determination rule one obtains

$$
\begin{aligned}
\left(r+\lambda_{o}+s\right) S(l) & =\Delta+l^{\alpha}-b-\rho l+\lambda_{o}\left[\operatorname{Max}\left(S^{d}(l) ; 0\right)\right]-\theta q(\theta) \beta S(l) \\
\left(r+\lambda_{1}+s\right) S^{d}(l) & =\Delta-b-\rho l+\lambda_{1}\left[S(l)-S^{d}(l)\right]-\theta q(\theta) \beta S(l)
\end{aligned}
$$

The value of leverage, reads

$$
l^{*}=\arg \max \frac{-c+q(\theta)(1-\beta) S(l)}{r+q(\theta)}
$$

while job creation is simply

$$
\frac{c}{q(\theta)}=(1-\beta) S(l)
$$

The solution of the model crucially depends on the optimal job destruction threshold, conditional on an adverse financial shock $\lambda_{o}$. We define two types of equiibria depending on whether the firm operates or not in financial distress. In particular we let

$$
\begin{aligned}
S^{d}(l) & =\operatorname{Max}\left[0 ; S^{d}(l)\right] & & \text { Low credit equilibrium } \\
0 & =\operatorname{Max}\left[0 ; S^{d}(l)\right] & & \text { High credit equilibrium }
\end{aligned}
$$

and the characterization of the two equilibria will be determined in terms of $\rho$, the cost of credit. The key parameter for discriminating between the two equilibria will be the marginal cost of credit.

\subsection{High Credit Equilibrium}

In the high credit equilibrium, firms destroy jobs in financial distress. The value of the surplus in normal condition determines immediately the optimal leverage $l^{*}$ equating the marginal benefits of an additional unit of leverage to its marginal cost so that

$$
\rho=\alpha l^{\alpha-1}
$$

as

$$
l^{*}=\left(\frac{\alpha}{\rho}\right)^{\frac{1}{1-\alpha}}
$$

Proposition 2 In a high credit market equilibrium, optimal leverage is independent of the arrival rate of financial shocks and it depends only on its marginal cost and its marginal impact on productivity. 
The optimal job creation is

$$
\begin{aligned}
\frac{c}{q(\theta)} & =(1-\beta) S(l) \\
\frac{c}{q(\theta)} & =(1-\beta)\left[\frac{\Delta+l^{\alpha}-\rho l-b}{r+\lambda_{o}+s+\beta \theta q(\theta)}\right] \\
\frac{c\left(r+\lambda_{o}+s\right)}{q(\theta)}+c \theta \beta & =(1-\beta)\left[\Delta+l^{\alpha}-\rho l-b\right]
\end{aligned}
$$

where in the last condition we substituted for the free entry condition in the surplus condition.

Proposition 3 A higher cost of credit and a higher arrival rate of financial shocks reduce market tightness and job creation

Proof: $\frac{\partial \theta}{\partial \rho}<0 ; \frac{\partial \theta}{\partial \lambda_{0}}<0$

The unemployment rate is

$$
u=\frac{s+\lambda_{o}}{s+\lambda_{o}+\theta q(\theta)}
$$

Proposition 4 In the high credit equilibrium an increase in $\lambda_{0}$ has an adverse direct impact on unemployment (through an increase in job destruction) and an adverse indirect impact through job creation (the reduction in market tightness)

To characterize a high credit equilibrium, the key condition is

$$
J^{d}(l)<0
$$

Using the definition of surplus and wage determination, the surplus in distress reads

$$
\begin{aligned}
& \left(r+\lambda_{1}+s\right) S^{d}(l)=\Delta-b-\rho l+\left(\lambda_{1}-\theta q(\theta) \beta\right) S(l) \\
& \left(r+\lambda_{1}+s\right) S^{d}(l)=\Delta-b-\rho l+\left(\lambda_{1}-\theta q(\theta) \beta\right)\left[\frac{\Delta+l^{\alpha}-\rho l-b}{r+\lambda_{o}+s+\beta \theta q(\theta)}\right]
\end{aligned}
$$

so that the condition is

$$
\begin{aligned}
\Delta-b-\rho l+\left(\lambda_{1}-\theta q(\theta) \beta\right)\left[\frac{\Delta+l^{\alpha}-\rho l-b}{r+\lambda_{o}+s+\beta \theta q(\theta)}\right] & <0 \\
(\Delta-b)\left(r+\lambda_{o}+s+\lambda_{1}\right) & <\left(r+\lambda_{o}+s+\lambda_{1}\right) \rho^{-\frac{\alpha}{1-\alpha}} \alpha^{\frac{1}{1-\alpha}}-\left(\lambda_{1}-\theta q(\theta) \beta\right) \rho^{-\frac{\alpha}{1-\alpha}} \alpha^{\frac{\alpha}{1-\alpha}}
\end{aligned}
$$

where we substituted $l=l^{* h c}$. The previous condition suggests that we have a high credit equilibrium as long as

$$
\rho \leq \rho^{h c}=\left[\frac{\left(r+\lambda_{o}+s+\lambda_{1}\right) \rho^{-\frac{\alpha}{1-\alpha}} \alpha^{\frac{1}{1-\alpha}}-\left(\lambda_{1}-\theta q(\theta) \beta\right) \alpha^{\frac{\alpha}{1-\alpha}}}{(\Delta-b)\left(r+\lambda_{o}+s+\lambda_{1}\right)}\right]^{\frac{1-\alpha}{\alpha}}
$$

\subsection{Low Credit Equilibrium}

In the low credit equilibrium firms operate in financial distress,

$$
J^{d}(l)=\operatorname{Max}\left[J^{d}(l) ; 0\right]
$$

The surplus in the two states reads

$$
\begin{aligned}
(r+s) S(l) & =\Delta+l^{\alpha}-b-\rho l+\lambda_{o}\left[S^{d}(l)-S(l)\right]-\alpha(\theta) \beta S(l) \\
(r+s) S^{d}(l) & =\Delta-b-\rho l+\lambda_{1}\left[S(l)-S^{d}(l)\right]-\alpha(\theta) \beta S(l)
\end{aligned}
$$


From which it immediately follows that the net difference between two two surplus is proportional to leverage

$$
S(l)-S^{d}(l)=\frac{l^{\alpha}}{r+s+\lambda_{o}+\lambda_{1}}
$$

Making use of the previous expression, the optimal leverage in the low credit equilibrium is

$$
l^{*}=\left(\frac{\alpha \phi}{\rho}\right)^{\frac{1}{1-\alpha}}
$$

where $\phi=\frac{r+s+\lambda_{1}}{r+s+\lambda_{o}+\lambda_{1}}$. Two simple propositions immediately follow.

Proposition 5 For a given set of parameters, leverage in the low credit equilibrium is lower than in the high credit equilibrium.

Proposition 6 Financial parameters affect optimal leverage in the low credit equilibrium. In particular, a higher arrival rate of financial shocks reduces leverage $\left(\frac{\partial l^{*}}{\partial \lambda_{o}} \leq 0\right)$ while a shorter duration of distress increases leverage $\frac{\partial l^{*}}{\partial \lambda_{1}} \geq 0$

The condition for optimal job creation is

$$
\begin{aligned}
\frac{c}{q(\theta)} & =(1-\beta)\left[\frac{\Delta+l^{\alpha}-\rho l-\bar{\lambda}_{o} l^{\alpha}}{r+s+\beta \theta q(\theta)}\right] \\
\frac{c(r+s)}{q(\theta)}+\beta c \theta & =(1-\beta)\left[\Delta+l^{\alpha}-\rho l-\bar{\lambda}_{o} l^{\alpha}\right]
\end{aligned}
$$

where $\bar{\lambda}_{0}=\frac{\lambda_{o}}{r+s+\lambda_{1}+\lambda_{o}}$

Proposition 7 In a low credit equilibrium, a larger financial shock and a shorter financial distress reduce job creation: $\frac{\partial \theta}{\partial \lambda_{o}}<0 ;$ and $\frac{\partial \theta}{\partial \lambda_{1}}>0$

Unemployment in the low credit equilibrium is given by

$$
u=\frac{s}{s+\theta q(\theta)}
$$

This has two important implications.

Proposition 8 An increase in the intensity of the financial crisis $\lambda_{o}$ has no direct impact on unemployment in the low credit equilibrium, since it only operates through job creation.

Proposition 9 In the low credit equilibrium, financial market variables operate only through job creation and have no direct impact on job destruction.

The condition for the low credit market equilibrium is

$$
\begin{gathered}
(r+s+\alpha(\theta) \beta) S^{d}(l)=\Delta-b-\rho l+\frac{\left(\lambda_{1}-\alpha(\theta) \beta\right) l^{\alpha}}{r+s+\lambda_{o}+\lambda_{1}}>0 \\
(\Delta-b)\left(r+s+\lambda_{0}+\lambda_{1}\right) \geq \rho^{-\frac{\alpha}{1-\alpha}} \alpha^{\frac{1}{1-\alpha}} \phi^{\frac{1}{1-\alpha}}+\left(\alpha(\theta) \beta-\lambda_{1}\right) \alpha^{\frac{\alpha}{1-\alpha}} \phi^{\frac{\alpha}{1-\alpha}}
\end{gathered}
$$

where we used the optimal leverage $l^{*}=\left(\frac{\alpha \phi}{\rho}\right)^{\frac{1}{1-\alpha}}$. The formal condition on the cost of credit is

$$
\rho \geq \rho^{l c}=\left[\frac{\left(r+\lambda_{o}+s+\lambda_{1}\right) \alpha^{\frac{1}{1-\alpha}} \phi^{\frac{1}{1-\alpha}}-\left(\lambda_{1}-\theta q(\theta) \beta\right) \alpha^{\frac{\alpha}{1-\alpha}} \phi^{\frac{1}{1-\alpha}}}{(\Delta-b)\left(r+\lambda_{o}+s+\lambda_{1}\right)}\right]^{\frac{1-\alpha}{\alpha}}
$$




\subsection{Multiple Equilibria}

Before considering the issue of multiple equilibria, we need to establish a simple and basic result related to the two regimes, namely the fact that in the high credit market equilibrium $\theta^{h c}>\theta^{l c}$.

Proposition 10 In the high credit market equilibrium job creation is higher and the labor market is tighter.

To prove the proposition consider the two job creation conditions

$$
\begin{aligned}
\frac{\left(r+s+\lambda_{0}\right) c}{q\left(\theta^{h c}\right)}+\theta^{h c} \beta c & =(1-\beta)\left[\Delta+l^{h c \alpha}-\rho l^{h c}-b\right] \\
\frac{(r+s) c}{q\left(\theta^{l c}\right)}+\theta^{l c} \beta c & =(1-\beta)\left[\Delta+\left(1-\lambda_{o}\right) l^{l c \alpha}-\rho l^{l c}-b\right]
\end{aligned}
$$

So that subtracting each side we obtain

$$
(r+s) c\left[\frac{1}{q\left(\theta^{h c}\right)}-\frac{1}{q\left(\theta^{l c}\right)}\right]+\frac{\lambda_{0} c}{q\left(\theta^{h c}\right)}+\beta c\left[\theta^{h c}-\theta^{l c}\right]=(1-\beta)\left[l^{h c \alpha}-\rho l^{h c}-\left(\left(1-\bar{\lambda}_{o}\right) l^{l c \alpha}-\rho l^{l c}\right)\right]
$$

Substituting for $\left(1-\bar{\lambda}_{o}\right)=\phi, l^{h c}=\rho^{-\frac{1}{1-\alpha}} \alpha^{\frac{1}{1-\alpha}} ; l^{c c}=\rho^{-\frac{1}{1-\alpha}} \alpha^{\frac{1}{1-\alpha}} \phi^{\frac{1}{1-\alpha}}$, and noting that $\phi l^{l c \alpha}=\rho^{-\frac{\alpha}{1-\alpha}} \alpha^{\frac{\alpha}{1-\alpha}} \phi^{\frac{1}{1-\alpha}}$ one has that

$$
(1-\beta)\left[l^{h c \alpha}-\rho l^{h c}-\left(\left(1-\bar{\lambda}_{o}\right) l^{l c \alpha}-\rho l^{l c}\right)\right]=\left[1-\phi^{\frac{1}{1-\alpha}}\right] \rho^{-\frac{\alpha}{1-\alpha}}\left[\alpha^{\frac{\alpha}{1-\alpha}}-\alpha^{\frac{1}{1-\alpha}}\right]>0
$$

so that the right-hand-side is positive and implies that $\theta^{h c}>\theta^{l c}$ for the left-hand-side to be positive.

Let us now turn to the multiple equilibria issue. While a cost of credit $\rho$ large enough ensures a low credit equilibrium, a cost of credit low enough supports a high credit equilibrium. A sufficient condition for the existence of multiple equilibria is that $\rho^{h c}>\rho^{l c}$. Comparing the two cutoff costs $\rho^{l c}$ and $\rho^{h c}$, one can show that $\theta^{h c}=\theta^{l c}=\theta$

$$
\begin{aligned}
\rho^{h c} & >\rho^{l c} \text { if } \\
{\left[R \alpha^{\frac{1}{1-\alpha}}+\beta \theta q(\theta) \alpha^{\frac{\alpha}{1-\alpha}}-\lambda_{1} \alpha^{\frac{\alpha}{1-\alpha}}\right] } & >\left[R \alpha^{\frac{1}{1-\alpha}} \phi^{\frac{1}{1-\alpha}}+\beta \theta q(\theta) \alpha^{\frac{\alpha}{1-\alpha}} \phi^{\frac{\alpha}{1-\alpha}}-\lambda_{1} \alpha^{\frac{\alpha}{1-\alpha}} \phi^{\frac{\alpha}{1-\alpha}}\right] \\
R \alpha^{\frac{1}{1-\alpha}}\left(1-\phi^{\frac{1}{1-\alpha}}\right)+\left(\beta \theta q(\theta)-\lambda_{1}\right) \alpha^{\frac{\alpha}{1-\alpha}}\left(1-\phi^{\frac{1}{1-\alpha}}\right) & >0 \\
\text { if } \beta \theta q(\theta) & >\lambda_{1}
\end{aligned}
$$

Since $\theta^{h c} \geq \theta^{l c}$ the previous inequality is reinforced.

\subsection{An Increase in Financial Shock in the Two Regimes}

While the model is static in nature, we can use an increase in the shock arrival rate as a way to study aggregate dynamics. An increase in $\lambda_{o}$ is akin to an aggregate financial shock. The idea is that in the aftermath of an increase in $\lambda_{o}$ the high credit market equilibrium features a larger response in unemployment. The result is easily established by the following proposition.

Proposition 11 In the high credit market equilibrium unemployment responds more to an adverse financial shock, or to an increase in $\lambda_{0}$

$$
\begin{aligned}
\left.\frac{\partial u}{\partial \lambda_{o}}\right|_{\text {High Credit }} & =\frac{\theta q(\theta)}{\left[s+\lambda_{o}+\theta q(\theta)\right]^{2}}+\frac{-\frac{\partial \theta q(\theta)}{\partial \lambda_{o}}}{\left[s+\lambda_{o}+\theta q(\theta)\right]^{2}}>0 \\
& =[\text { Increase Job Destruction] }+[\text { Decrease Job Creation] }
\end{aligned}
$$


Table 2: Job creation and Job destruction in Low and High Leverage sectors

\begin{tabular}{l|c|cc|cc|}
\hline \hline & & \multicolumn{2}{|c|}{ job destruction } & \multicolumn{2}{c|}{ job creation } \\
\hline Country & year & high & low & high & low \\
\hline Finland & 1997 & 9.204 & 8.942 & 12.783 & 13.668 \\
Germany & $1996-1998$ & 8.516 & 8.044 & 6.790 & 7.593 \\
Sweden & $1996-2004$ & 7.342 & - & 8.186 & - \\
United Kingdom & $1996-1999$ & 12.897 & - & 13.344 & - \\
United States & $2000-2005$ & 15.817 & 11.087 & 19.205 & 11.416 \\
\hline \hline
\end{tabular}

$$
\begin{aligned}
\left.\frac{\partial u}{\partial \lambda_{o}}\right|_{\text {Low Credit }} & =\frac{-\frac{\partial \theta q(\theta)}{\partial \lambda_{o}}}{[s+\theta q(\theta)]^{2}}>0 \\
& =[\text { Decrease Job Creation }]
\end{aligned}
$$

\section{Back to the Data}

The model above explains why financial crises originate larger employment variations than ordinary crises. This is because there is an additional effect on productivity than during "ordinary" recessions, coming from the forced reduction in the use of the finance-input in the production process. The model also yields some testable empirical implications. In particular, it implies that high leverage equilibria involve larger variations in employment during financial crises than low leverage equilibria because in the former the effect is felt both on the job creation and the job destruction margins, while in the latter only on job creation.

In this section we test these empirical implications of the model.

Unfortunately there is not a time-series of job creation and job destruction rates by country and sector. Work carried out at the OECD by Andrea Bassanini (2010) produced a cross section of comparable job turnover data for 4 sectors (industry, construction, financial services and trade) in 6 OECD countries (Finland, Germany, Portugal, Sweden, United Kingdom and US). Table 2 shows these average period gross job creation and job destruction rates by country and by degree of leverage of the sectors involved. In particular, low leverage refers to average job turnover data for industry and trade and high leverage for average job turnover rates in construction and financial services as several datasets (including the Imf dataset used below) suggest that there is a marked difference between these two group of sectors in terms of both, debnt-to-sales and debt-to-assets ratios. As we can see, job destruction rates are larger in sectors with higher leverage, whereas there is not a clearcut difference in job creation.

In order to assess the effects of financial crises on job creation and destruction by degree of leverage, we need to use another dataset on net employment variation and leverage by sector. In particular, we estimate below the contribution of leverage to the increase in employment-to-output elasticities during financial recessions by drawing on a unique Imf dataset of quarterly data on employment, value added, debt-to-sales and debt-to-assets ratios by country and sector in OECD countries. Before describing the data, it is useful to consider the empirical framework adopted in our analysis and provide further details on the taxonomy of recessions that will be used in our estimates.

\subsection{Estimation framework}

The three sources of variation in our data (time-series, cross-country, cross-industry) allow us to cope with the different types of interactions pointed out by the model presented in the previous section. In particular, we can identify the effects of financial variables on emplo,yment adjustment by drawing on time-series variation within each country and sector, controlling for fixed country and industry characteristics influencing the responsiveness of employment to output. 
Our estimation framework is akin an augmented Okun's law for employment. In particular, our dependent variable is the log variation in employment while, on the right-hand-side we control for fixed country and sector effects affecting the intercept (hence the minimum level of output growth inducing employment growth), output growth by itself as well as interacted with indicators of financial recessions, leverage ratios and time varying institutions potentially affecting the employment responsiveness to output changes. Formally, the model that we estimate is as follows:

$$
\begin{array}{r}
\Delta e i j t=\alpha_{j}+\alpha_{i}+\beta \Delta y_{i j t}\left[1+\gamma_{1} L_{e v_{i j t}}+\gamma_{2} F C_{i t}+\gamma_{3} * F C_{i t} * L e v_{i j t}\right. \\
\left.+\delta X_{i j t}\right]+\epsilon_{i j t}
\end{array}
$$

where $\Delta$ eijt is $\log$ employment variation in country $i$, sector $j$ at time $t, \alpha_{j}$ and $\alpha_{i}$ denote the coefficients of sectoral and country dummies respectively, $\Delta y$ is the log variation in output, Lev is the leverage ratio (either debt-to-assets or debt-to-sales), $F C$ denotes financial recessions, and $X$ a set of time-varying institutional variables potentially affecting the responsiveness of employment to output change. As the literature points to a large number of institutions which may affect labor-finance interactions depending on the degree of leverage of different industries, we also include country-sector dummies. This amounts essentially for identifying the effect of financial variables on employment adjustment via time-series variation. In some specifications, we also cluster observations by sector, year and country.

Our key parameter of interest is $\gamma_{3}$ denoting the effects of leverage on the Okun's elasticity during financial recessions.

A problem with this framework is that the presence of leverage on the righ-hand-side of the estimated equation poses a potential problem of endogeneity. Firms' hiring policies are indeed likely to affect the degree of leverage of firms and this could bias our estimates. We tackle this issue in two ways. In our first empirical strategy we parametrize leverage by operating on the distribution of debt-to-assets and debt-to-sales ratios over the entire period. The alternative strategy is to use current values for the leverage ratios but impose an exclusion restriction, defining variables that are correlated with leverage but not with $\epsilon_{i j t}$.

Before turning to our estimates, we need to explain how we identify the recessions considered in our model and provide further details on the data at hand.

\subsection{Identifying Credit Shocks}

The model has implications related to credit shocks, involving an unexpected reduction in credit flows to firms. There are two taxonomies of financial crises, we can draw upon in our empirical analysis.

The first taxonomy was also introduced in Section 2 and was developed by Reinhart and Rogoff (2008) (RR henceforth). It captures a relatively large set of recessions involving the financial sector, including housing booms-bust sequences. The second taxonomy was developed by Atkinson and Morelli (2011) (AM henceforth) and is focused only on banking crises, it looks precisely at those shocks that affect access by firms to liquid assets. Atkinson and Morelli identified 8 banking crisis episodes in some 13 countries in the years 1965 to 2009. A banking crisis is, according to this definition, one where any of the following three conditions is met:

1. there are bank runs that lead to the closure, merging, or takeover by the public sector of one or more financial institutions;

2. there are no bank runs, but the closure, merging, takeover, or large-scale government assistance of an important financial institution (or group of institutions), that marks the start of a string of similar outcomes for other financial institutions;

3. a country's corporate and financial sectors experience a large number of defaults, and financial institutions and corporations face great difficulties repaying contracts on time.

The first two criteria correspond to those used by Reinhart and Rogoff (2008) (RR henceforth) in their taxonomy of crises, while the third one was proposed by Laeven and Valencia (2008). 
Table 3: Number and average duration of banking crises in different countries

\begin{tabular}{lcccc}
\hline \hline & \multicolumn{2}{c}{$\begin{array}{c}\text { banking crises } \\
\text { (Morelli) }\end{array}$} & \multicolumn{2}{c}{$\begin{array}{c}\text { other crises } \\
\text { NBER }\end{array}$} \\
\hline country & $\begin{array}{c}\text { avg lenght } \\
\text { (qrt) }\end{array}$ & $\begin{array}{c}\text { nr of } \\
\text { episodes }\end{array}$ & $\begin{array}{c}\text { avg lenght } \\
\text { (qrt) }\end{array}$ & $\begin{array}{c}\text { nr of } \\
\text { episodes }\end{array}$ \\
\hline Australia & & & 1 & 1 \\
Belgium & & & 3 & 1 \\
Canada & & & 3.5 & 2 \\
France & & 1 & 3 & 3 \\
Finland & 4 & & & \\
Denmark & & & 3.33 & 3 \\
Germany & 4 & 1 & 5 & 3 \\
Ireland & & & & \\
Italy & 4 & 1 & 3.5 & 2 \\
Netherlands & 1 & 1 & 2 & 2 \\
Norway & & & 2 & 2 \\
Portugal & & & 4 & 1 \\
Spain & 4 & 1 & & \\
Sweden & & & & \\
UK & 4 & 1 & & \\
$\quad$ US & 4 & 2 & & \\
\hline \hline
\end{tabular}

We believe that the AM taxonomy is closest in spirit to our model as it signals episodes in which firms experience a sudden reduction the access to credit. A problem with this taxonomy is however that financial crises are identified over yearly data while we have data at quarterly frequencies. Thus, in the empirical analysis we used a second source of data on financial crises, notably from the IMF's 2010 World Economic Outlook (Chapter 3) to determine the length of recessions at quarterly frequencies. In other words, we identified a crisis year by using AM and then we determined the duration of the crisis at quarterly frequencies by using the IMF-WEO database. ${ }^{1}$.

Table 3 displays an overview of the number and average duration of banking crises in the countries in our sample and compare them with the other crises listed by the NBER.

As shown by the table, there are 8 banking crises in our sample, involving 7 countries. The average duration of these crises is in most of these countries longer than the duration of an "ordinary" crisis.

\subsection{Data}

We have access to data on employment and leverage ratios (debt-to-sales and debt-to-assets ratios) by 6 sectors (agriculture, construction, finance, industry, public administration, and trade) in 11 OECD countries (Australia, Austria, Belgium, Canada, Denmark, Finland, France, Germany, Greece, Ireland, Italy, Netherlands, Norway, Portugal, Spain, Sweden, United Kingdom, United States) in the period 1985-2008. Data come from the IMF - WDI Database and from the STAN archive of the OECD.

As some figures on debt-to-sales and debt-to-assets ratios were implausibly large, we removed observations above the 96 th percentile.

Table 4 displays descriptive statistics of the key variables used in the empirical analysis. In particular, our key covariates are the debt-to-sales assets and debt-to-assets ratios (available at yearly frequencies for each sector) as well as the OECD index of strictness of employment protection (EPL) (available at the

\footnotetext{
${ }^{1}$ In the few cases in which AM identified a country-year of crisis that was not recorded in the IMF data, we considered all quarters as crisis periods.
} 
Table 4: Descriptive Statistics

\begin{tabular}{lccccc}
\hline \hline Variable & Obs & Mean & Std. Dev. & Min & Max \\
\hline Debt to Sales & 3332 & 93.998 & 125.466 & 0.000 & 540.120 \\
Debt to Assets & 3332 & 23.431 & 10.169 & 0.000 & 62.160 \\
$\Delta$ employment & 5270 & 0.002 & 0.023 & -0.178 & 0.197 \\
$\Delta$ GDP & 5270 & 0.005 & 0.028 & -0.341 & 0.403 \\
EPL index & 4708 & 1.927 & 1.052 & 0.210 & 3.670 \\
STW & 4036 & 0.040 & 0.143 & 0.000 & 0.898 \\
UB & 4000 & 0.306 & 0.190 & 0.005 & 0.650 \\
\hline \hline
\end{tabular}

country-level at yearly frequencies), the OECD summary measure of generosity of unemployment benefits and a measure for the take-up of short-time working schemes (fraction of the labor force involved).

The time-series behavior of the two main measures of leverage available in our dataset is characterized in Figures $\mathrm{A}$ and $\mathrm{A}$ in the Annex. In particular, debt-to-asset and debt-to-sales ratios are displayed in conjunction with the GDP growth rate. Leverage ratios do not display a marked cyclical behavior, except in France where debt-to-sales ratios are mildly counter-cyclical (the correlation coefficient is -. 43 and is significant at 95 per cent). As shown by the diagrams and by table A.1 in the Annex, there is a substantial time-series variation in leverage and labor market statistics. This is encouraging in light of the estimation framework proposed below.

\section{Results}

Table 4 displays descriptive statistics on unconditional Okun's law elasticities estimated in each country and sector according to equation 2. Notice that in Canada and Sweden, the average employment-to-output elasticity is negative. Negative elasticities are also estimated for other countries, and are largely concentrated in agriculture. Hence, we decided to omit Canada, Sweden and agriculture from our analysis. We also decided not to consider the public sector as it is not clear how to define the budget constraint and the credit squeeze in this case.

\subsection{Regressions with a high-leverage dummy}

Our first empirical strategy involves developing a time-invariant measure of leverage based on the entire distribution of debt-to-sales and debt-to-assets ratios. In particular, the dummy $h i g h_{D} A$ or $h i g h_{D} S$ takes value 1 if the average of the debt-to-assets (DA) or debt-to-sales (DS) ratios for each country and sector in the years featuring no financial or banking crises is located in the top $40 \%$ of the distribution, and 0 otherwise. The list of highly-leveraged sectors and countries is provided in tabel A.3 in the Annex. As some sectors in all countries are structurally more leveraged, we also develop a second measure which draws on the DA and DS distribution specific to each sector, notably taking the US, industry specific, average-period debt-to-assets and debt-to-sales ratios as reference. The implicit assumption is that in the US, where financial markets are more developed, firms do actually choose in normal time the optimal degree of leverage without being seriously credit constrained. In this second definition, sectors with DA or DS ratios larger than $3 / 2$ of the US level for that sector are defined as highly leveraged.

Table 5 shows the results of a simple OLS regression in which the variation in employment is regressed against the variation in output, together with our alternative measure for high leverage, the dummy for the financial crisis, the interaction of financial crisis with hgh-leverage, as well as institutional variables. Each of these regressors is interacted with the variation in output, to highlight the contribution of these variables to the Okun's elasticity.

In all our specifications, the coefficient on the triple interaction leverage-financial crisis-output variation 
Table 5: Effects of Leverage on Okun's elasticities - Using dummy for High Leverage (DS - DA)

\begin{tabular}{|c|c|c|c|c|c|c|}
\hline & $(1)$ & $(2)$ & $(3)$ & $(4)$ & $\overline{(5)}$ & (6) \\
\hline VARIABLES & $\Delta e$ & $\Delta e$ & $\Delta e$ & $\Delta e$ & & \\
\hline$\Delta y$ & $\begin{array}{c}0.2698^{* *} \\
(0.109)\end{array}$ & $\begin{array}{c}0.2679^{* *} \\
(0.103)\end{array}$ & $\begin{array}{c}0.2919^{* * *} \\
(0.097)\end{array}$ & $\begin{array}{c}0.2698^{* *} \\
(0.109)\end{array}$ & $\begin{array}{c}0.2679^{* *} \\
(0.103)\end{array}$ & $\begin{array}{c}0.2919^{* * *} \\
(0.097)\end{array}$ \\
\hline $\mathrm{FC} * \Delta y$ & $\begin{array}{c}-0.3130 * * * \\
(0.101)\end{array}$ & $\begin{array}{c}-0.4532^{* * *} \\
(0.099)\end{array}$ & $\begin{array}{c}-0.3299 * * * \\
(0.088)\end{array}$ & $\begin{array}{c}-0.3130^{* * *} \\
(0.101)\end{array}$ & $\begin{array}{c}-0.4532^{* * *} \\
(0.099)\end{array}$ & $\begin{array}{c}-0.3299^{* * *} \\
(0.088)\end{array}$ \\
\hline $\mathrm{DS} * \Delta y$ & $\begin{array}{c}0.1137^{*} \\
(0.056)\end{array}$ & $\begin{array}{l}0.0283 \\
(0.060)\end{array}$ & $\begin{array}{c}0.1115^{*} \\
(0.062)\end{array}$ & & & \\
\hline $\mathrm{DS}^{*} \mathrm{FC} * \Delta y$ & $\begin{array}{c}0.7049^{* * *} \\
(0.051)\end{array}$ & $\begin{array}{c}0.7871^{* * *} \\
(0.051)\end{array}$ & $\begin{array}{c}0.6752^{* * *} \\
(0.069)\end{array}$ & & & \\
\hline $\mathrm{DA} * \Delta y$ & & & & $\begin{array}{c}0.1137^{*} \\
(0.056)\end{array}$ & $\begin{array}{c}0.0283 \\
(0.060)\end{array}$ & $\begin{array}{c}0.1115^{*} \\
(0.062)\end{array}$ \\
\hline $\mathrm{DA} * \mathrm{FC} * \Delta y$ & & & & $\begin{array}{c}0.7049^{* * *} * \\
(0.051)\end{array}$ & $\begin{array}{c}0.7871^{* * *} \\
(0.051)\end{array}$ & $\begin{array}{c}0.6752^{* * *} \\
(0.069)\end{array}$ \\
\hline low EPL $* \Delta y$ & $\begin{array}{c}-0.0232 \\
(0.073)\end{array}$ & $\begin{array}{r}-0.0018 \\
(0.070)\end{array}$ & $\begin{array}{l}-0.0154 \\
(0.066)\end{array}$ & $\begin{array}{c}-0.0232 \\
(0.073)\end{array}$ & $\begin{array}{r}-0.0018 \\
(0.070)\end{array}$ & $\begin{array}{c}-0.0154 \\
(0.066)\end{array}$ \\
\hline $\mathrm{STW}^{*} \Delta y$ & $\begin{array}{l}-0.0999 \\
(0.154)\end{array}$ & $\begin{array}{c}-0.1349 \\
(0.126)\end{array}$ & $\begin{array}{r}-0.1645 \\
(0.153)\end{array}$ & $\begin{array}{c}-0.0999 \\
(0.154)\end{array}$ & $\begin{array}{c}-0.1349 \\
(0.126)\end{array}$ & $\begin{array}{c}-0.1645 \\
(0.153)\end{array}$ \\
\hline $\mathrm{UB} * \Delta y$ & $\begin{array}{r}-0.2329 \\
(0.217)\end{array}$ & $\begin{array}{r}-0.2079 \\
(0.192)\end{array}$ & $\begin{array}{r}-0.3195 \\
(0.208)\end{array}$ & $\begin{array}{r}-0.2329 \\
(0.217)\end{array}$ & $\begin{array}{r}-0.2079 \\
(0.192)\end{array}$ & $\begin{array}{r}-0.3195 \\
(0.208)\end{array}$ \\
\hline Constant & $\begin{array}{c}0.0010 \\
(0.001)\end{array}$ & $\begin{array}{c}0.0011 \\
(0.001)\end{array}$ & $\begin{array}{l}0.0010 \\
(0.001)\end{array}$ & $\begin{array}{l}0.0010 \\
(0.001)\end{array}$ & $\begin{array}{l}0.0011 \\
(0.001)\end{array}$ & $\begin{array}{l}0.0010 \\
(0.001)\end{array}$ \\
\hline Fixed Effects & No & Sector & Country & No & Sector & Country \\
\hline Observations & 1,748 & 1,748 & 1,748 & 1,748 & 1,748 & 1,748 \\
\hline R-squared & 0.070 & 0.111 & 0.091 & 0.070 & 0.111 & 0.091 \\
\hline
\end{tabular}

is positive and statistically significant: this shows how more leveraged sectors are those who suffer more, in terms of job losses, during financial crises. Leverage is found to increase Okun's elasticities also outside financial recessions, while, controlling for leverage, financial recessions by themselves reduce the elasticity of employment to output. This incidentally provides an explanation for the stylized fact captured in Section 2: the higher Okun's elasticity typically observed during financial crises is driven by the adjustment of the highly leveraged sectors.

Significantly, institutional variables do not seem to exert a statistically significant effect on employmentto-output elasticities. This may be because these variables have only a time-series and cross-country variation, hence cannot contribute to explain cross-industry variation.

\subsection{Instrumenting Leverage}

Our second empirical strategy allows for time-series variation in leverage ratios. We simply carry out our regressions by using debt-to-sales ratios at quarterly frequencies. The results are displayed in Table 6 . They also indicate a positive effect of leverage on employment-to-output elasticities during financial crises while there is no effect in normal times. A problem with this specification is that leverage ratios are endogenous to hiring and firing decisions of firms, so that we cannot interpret our results as a causal effect of leverage on 
Table 6: OLS regressions with time-varying leverage

\begin{tabular}{|c|c|c|c|c|}
\hline & $\overline{(1)}$ & $\overline{(2)}$ & $\overline{(3)}$ & $\overline{(4)}$ \\
\hline VARIABLES & $\Delta e$ & $\Delta e$ & $\Delta e$ & $\Delta e$ \\
\hline$\Delta y$ & $\begin{array}{c}0.2789^{* *} \\
(0.113)\end{array}$ & $\begin{array}{c}0.2682^{* * *} \\
(0.078)\end{array}$ & $\begin{array}{c}0.2861^{* *} \\
(0.103)\end{array}$ & $\begin{array}{c}0.2994^{* * *} \\
(0.100)\end{array}$ \\
\hline $\mathrm{FC} * \Delta y$ & $\begin{array}{c}-0.6636^{* * *} \\
(0.104)\end{array}$ & $\begin{array}{c}-0.6528^{* * *} \\
(0.084)\end{array}$ & $\begin{array}{c}-0.7804^{* * *} \\
(0.104)\end{array}$ & $\begin{array}{c}-0.6766^{* * *} * \\
(0.089)\end{array}$ \\
\hline $\mathrm{DS} * \Delta y$ & $\begin{array}{l}0.0002 \\
(0.000)\end{array}$ & $\begin{array}{r}-0.0001 \\
(0.000)\end{array}$ & $\begin{array}{r}-0.0001 \\
(0.000)\end{array}$ & $\begin{array}{c}0.0002 \\
(0.000)\end{array}$ \\
\hline $\mathrm{DS} * \mathrm{FC}^{*} \Delta y$ & $\begin{array}{c}0.0077^{* * * *} \\
(0.000)\end{array}$ & $\begin{array}{c}0.0065^{* * *} \\
(0.001)\end{array}$ & $\begin{array}{c}0.0076^{* * * *} \\
(0.000)\end{array}$ & $\begin{array}{c}0.0075^{* * *} \\
(0.000)\end{array}$ \\
\hline low epl $* \Delta y$ & $\begin{array}{r}-0.0169 \\
(0.080)\end{array}$ & $\begin{array}{c}0.0364 \\
(0.073)\end{array}$ & $\begin{array}{c}0.0071 \\
(0.077)\end{array}$ & $\begin{array}{c}-0.0069 \\
(0.077)\end{array}$ \\
\hline $\mathrm{STW}^{*} \Delta y$ & $\begin{array}{c}-0.0611 \\
(0.123)\end{array}$ & $\begin{array}{c}-0.2206^{*} \\
(0.124)\end{array}$ & $\begin{array}{r}-0.1217 \\
(0.110)\end{array}$ & $\begin{array}{c}-0.1100 \\
(0.127)\end{array}$ \\
\hline $\mathrm{UB} * \Delta y$ & $\begin{array}{c}-0.2218 \\
(0.216)\end{array}$ & $\begin{array}{c}-0.2612 \\
(0.162)\end{array}$ & $\begin{array}{r}-0.2249 \\
(0.190)\end{array}$ & $\begin{array}{c}-0.3053 \\
(0.207)\end{array}$ \\
\hline Constant & $\begin{array}{l}0.0010 \\
(0.001)\end{array}$ & $\begin{array}{l}0.0012^{*} \\
(0.001)\end{array}$ & $\begin{array}{l}0.0011 \\
(0.001)\end{array}$ & $\begin{array}{l}0.0010 \\
(0.001)\end{array}$ \\
\hline Fixed Effects & No & Country x Sector & Sector & Country \\
\hline Observations & 1,748 & 1,748 & 1,748 & 1,748 \\
\hline R-squared & 0.067 & 0.157 & 0.110 & 0.088 \\
\hline
\end{tabular}

employment-to-output variation. In order to tackle this issue, we impose some exclusion restrictions enabling us to identify a causal effects of leverage on employment adjustment.

In particular, we used two instruments for leverage:

- DA and DS ratios lagged one period, and

- a measure of the average age of employers in each sector which should capture heterogeneity in discount factors, hence on leverage ratios.

The underlying assumption in choosing the first instrument is that lagged leverage in a sector is correlated with current leverage, but not with current employment adjustment. The exclusion restriction in the case of the second instrument is as follows: young managers are more prone to take risk: in this sense, their age should (negatively) affect leverage, while it should not affect employment variation. We draw on data from the European Union Labor Force Survey and use as instrument a dummy taking value 1 if the average age of managers, for each sector in each country in each year, is lower than 40.

Both instruments are significantly correlated with leverage ratios in the first-stage regression. We display here only the results using lagged leverage as instrument for current leverage (see table 7). Those using the age of managers are displayed in the Annex. In the second stage, the triple interaction between leverage, financial crisis and output variation is positive and statistically significant only when we use lagged DA and DS as instruments. 
Table 7: Two-Stages Least Squares - Instrument: Lagged Leverage

First Stage

\begin{tabular}{|c|c|c|c|c|}
\hline & (1) & (2) & (3) & (4) \\
\hline VARIABLES & $\mathrm{DS} * \Delta y$ & $\mathrm{DS}^{*} \mathrm{FC} * \Delta y$ & $\mathrm{DA} * \Delta y$ & $\mathrm{DA} * \mathrm{FC} * \Delta y$ \\
\hline \multirow[t]{2}{*}{$\Delta y$} & $90.7132^{* * *}$ & -0.2200 & $23.2855^{* * *}$ & 0.0583 \\
\hline & $(2.765)$ & $(0.467)$ & $(0.205)$ & $(0.048)$ \\
\hline \multirow[t]{2}{*}{$\mathrm{FC} * \Delta y$} & $-42.0324^{* * *}$ & $52.0613^{* * *}$ & $10.5733^{* * *}$ & $34.4662^{* * *}$ \\
\hline & $(9.599)$ & $(1.630)$ & $(0.708)$ & $(0.168)$ \\
\hline L.DS $* \Delta y$ & $\begin{array}{c}0.1875^{* * * *} \\
(0.017)\end{array}$ & & & \\
\hline L2.DS $* \Delta y$ & $\begin{array}{c}-0.0645^{* * *} \\
(0.017)\end{array}$ & & & \\
\hline \multirow[t]{2}{*}{ L.DS $* \mathrm{FC} * \Delta y$} & & & & \\
\hline & & $(0.018)$ & & \\
\hline $\mathrm{L} 2 . \mathrm{DS} * \mathrm{FC} * \Delta y$ & & $\begin{array}{c}0.0363^{* *} \\
(0.018)\end{array}$ & & \\
\hline L.DA * $\Delta y$ & & & $\begin{array}{c}0.0635^{* * *} \\
(0.008)\end{array}$ & \\
\hline $\mathrm{L} 2 . \mathrm{DA} * \Delta y$ & & & $\begin{array}{c}0.0319^{* * *} \\
(0.007)\end{array}$ & \\
\hline L.DA $* \mathrm{FC} * \Delta y$ & & & & $\begin{array}{c}-0.0156^{* * *} \\
(0.004)\end{array}$ \\
\hline $\mathrm{L} 2 . \mathrm{DA} * \mathrm{FC} * \Delta y$ & & & & $\begin{array}{c}-0.0285^{* * *} \\
(0.004)\end{array}$ \\
\hline \multirow[t]{2}{*}{ Constant } & 0.0573 & 0.0094 & $-0.0114^{* * *}$ & -0.0009 \\
\hline & $(0.046)$ & $(0.008)$ & $(0.003)$ & $(0.001)$ \\
\hline Observations & 2,506 & 2,506 & 2,506 & 2,506 \\
\hline R-squared & 0.435 & 0.562 & 0.883 & 0.960 \\
\hline
\end{tabular}

Second Stage

\begin{tabular}{|c|c|c|}
\hline & (1) & $(2)$ \\
\hline VARIABLES & $\Delta e$ & $\Delta e$ \\
\hline$\Delta y$ & $\begin{array}{c}-0.093^{*} \\
(0.056)\end{array}$ & $\begin{array}{c}-2.012^{* * *} \\
(0.217)\end{array}$ \\
\hline $\mathrm{FC} * \Delta y$ & $\begin{array}{c}0.029 \\
(0.136)\end{array}$ & $\begin{array}{c}5.990^{* * *} \\
(1.732)\end{array}$ \\
\hline low $\mathrm{EPL}^{*} \mathrm{FC} * \Delta y$ & $\begin{array}{c}-0.498^{* * *} \\
(0.110)\end{array}$ & $\begin{array}{c}-1.454^{* *} \\
(0.676)\end{array}$ \\
\hline $\mathrm{DS} * \Delta y$ & $\begin{array}{c}0.003^{* * *} \\
(0.001)\end{array}$ & \\
\hline $\mathrm{DS} * \mathrm{FC}^{*} \Delta y$ & $\begin{array}{c}0.009^{* * * *} \\
(0.002)\end{array}$ & \\
\hline $\mathrm{DA} * \Delta y$ & & $\begin{array}{c}0.094^{* * *} \\
(0.009)\end{array}$ \\
\hline $\mathrm{DA} * \mathrm{FC} * \Delta y$ & & $\begin{array}{c}-0.193^{* * *} \\
(0.049)\end{array}$ \\
\hline Constant & $\begin{array}{l}0.001^{*} \\
(0.000)\end{array}$ & $\begin{array}{c}0.001^{* * *} \\
(0.000)\end{array}$ \\
\hline Observations & 2,506 & 2,506 \\
\hline R-squared & 0.179 & 0.218 \\
\hline
\end{tabular}

Standard errors in parentheses *** $\mathrm{p}<0.01, * * \mathrm{p}<0.05, * \mathrm{p}<0.1$ 


\section{$6 \quad$ Final Remarks}

Empirical evidence suggests that financial shocks have important implications on labor market adjustment. This paper develops a simple model indicating that in highly leveraged equilibria there is not only a negative effect of recessions on job creation, but also an additional effect of financial shocks on the job destruction margin. We use a variety of datasets to test the implications of the model. We find that highly leveraged sectors are characterised by higher job destruction rates than low-leveraged sectors and that higher debtto-sales or debt-to-assets ratios are associated with higher employment-to-output elasticities during banking crises. If our identification assumptions are considered plausible, the relationship between leverage and employment adjustment can be interpreted as a causal effect.

\section{References}

[1] Ansgar, Belke, and Rainer Fehn, 2001, "Institutions and Structural Unemployment: Do Capital-Market Imperfections Matter?," Vienna Economics Papers 0106, University of Vienna, Department of Economics.

[2] Bernanke, Ben, and Mark Gertler, 1989, "Agency Costs, Net Worth and Business Fluctuations," American Economic Review, Vol. 79 (March), pp. 14-31.

[3] Bertola, Giuseppe, and Richard Rogerson, 1997 "Institutions and labor reallocation,"European Economic Review, 41(6): 1147-1171.

[4] Reinhart, Carmen, and Kenneth Rogoff, 2008, "Is the 2007 U.S. Sub-Prime Crisis So Different? An International Historical Comparison," NBER Working Paper No.13761 (Cambridge, Massachusetts: National Bureau of Economic Research).

[5] Gatti, Donatella, Rault, Christophe, and Anne-Gael Vaubourg, 2009, "Unemployment and Finance: How do Financial and Labour Market Factors Interact?, "CESifo Working Paper Series 2901, CESifo Group Munich.

[6] Koskela, Erkki, and Rune Stenbacka, 2001, "Equilibrium Unemployment with Credit and Labour Market Imperfections, "Bank of Finland Discussion Paper n. 5.

[7] Monacelli,Tommaso, Quadrini, Vincenzo, and Antonella Trigari, 2011, "Financial Markets and Unemployment,"NBER Working Papers 17389, National Bureau of Economic Research, Inc.

[8] Rendon, Sílvio, 2006, "Job Search And Asset Accumulation Under Borrowing Constraints, " International Economic Review (Institute of Social and Economic Research Association), vol. 47(1): 233-263.

[9] Wasmer, Etienne, and Philippe Weil, 2004, "The Macroeconomics of Labor and Credit Market Imperfections," American Economic Review (American Economic Association), 94(4): 944-963. 


\section{Appendix}

\section{A Statistical Annex}

Figure A.1: GDP and Debt to Assets
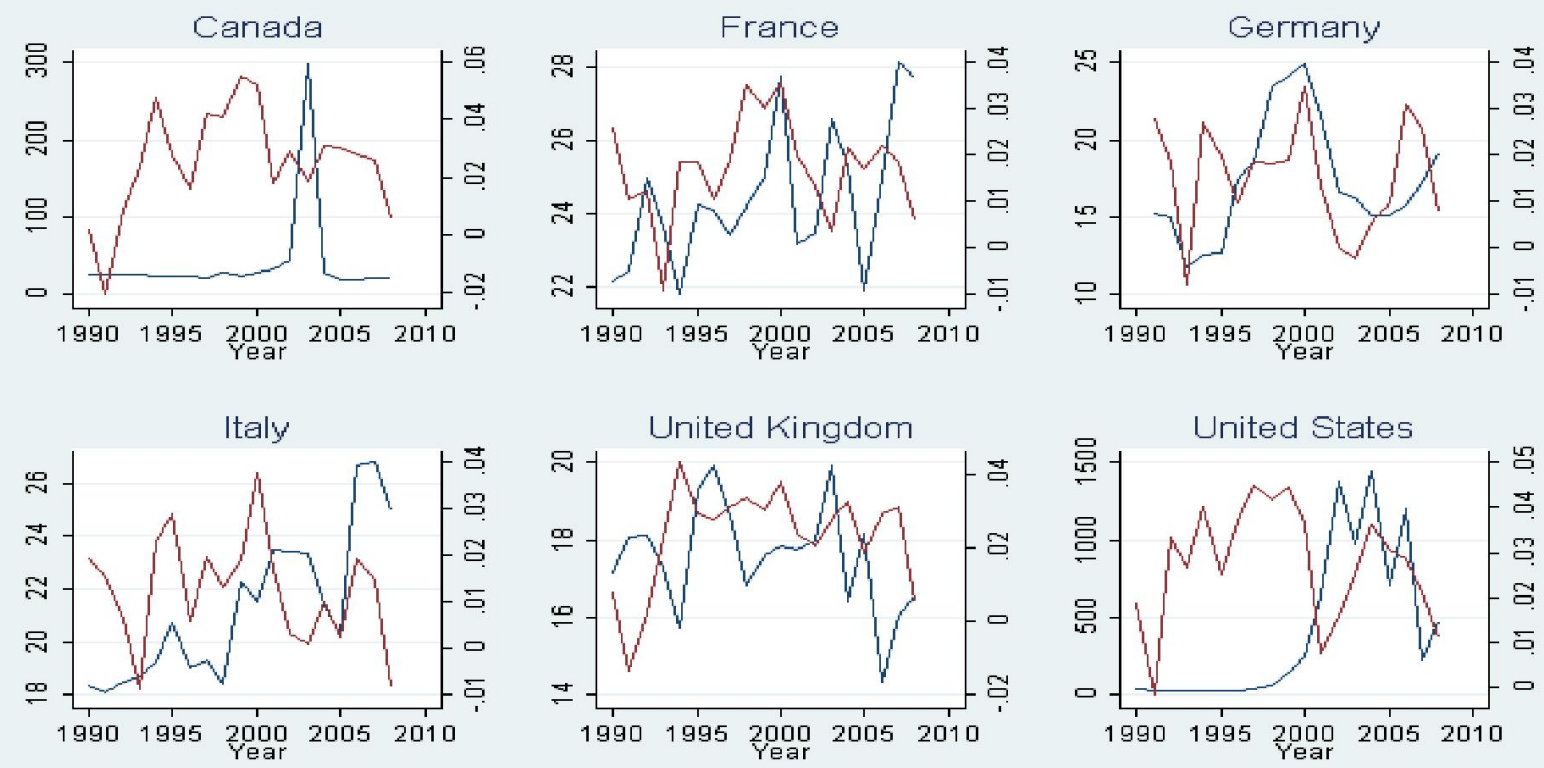

Note: blue line represents debt to asset; red line represents gdp growth left $Y$ axis measures debt to asset and right $Y$ axis measures gdp growth 
Figure A.2: GDP and Debt to Sales
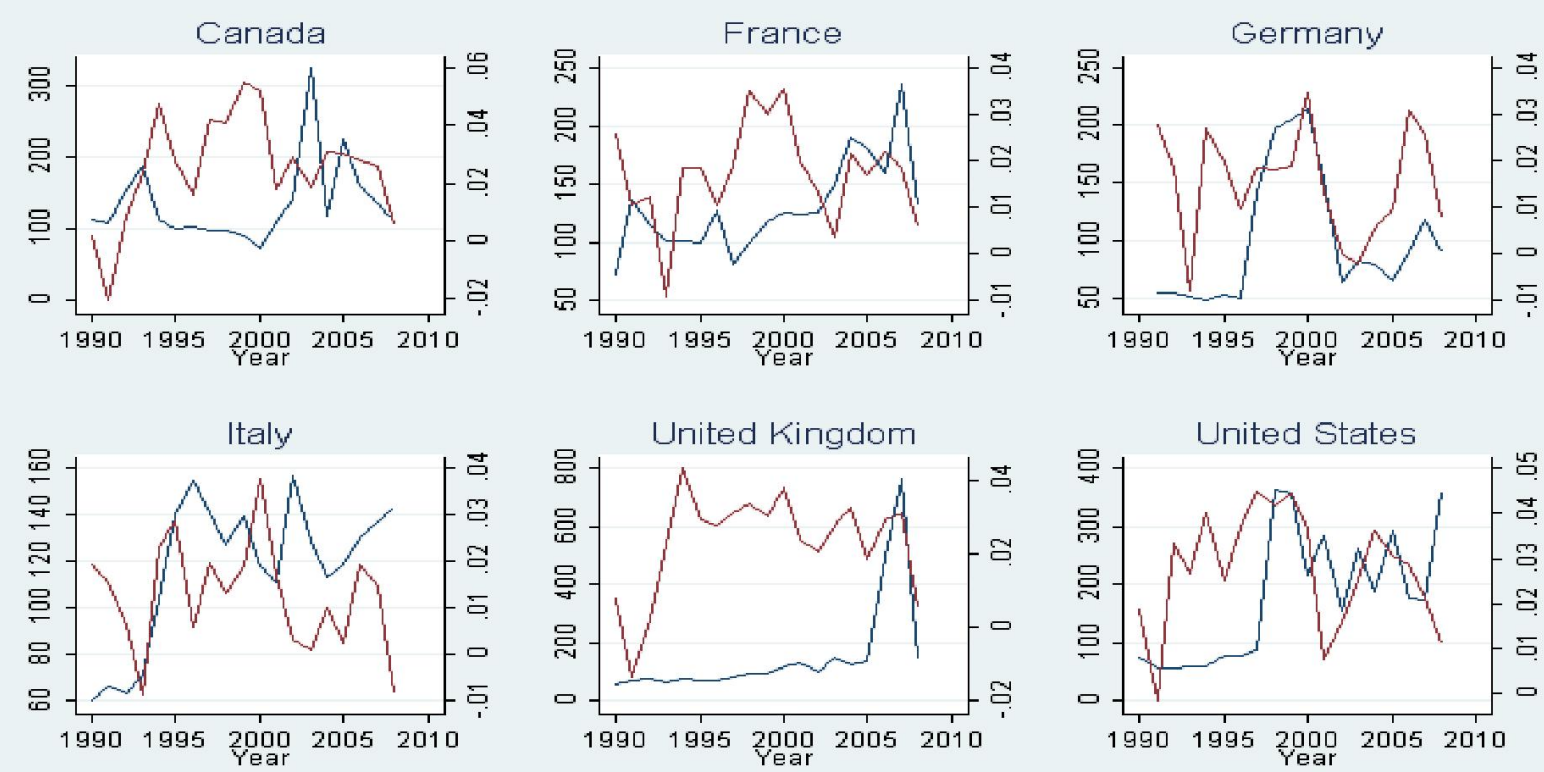

Note: blue line represents debt to sales and red line represents gdp growth left $\Upsilon$ axis measures debt to sales and right $Y$ axis measures gdp growth

Table A.1: Variance Decomposition

\begin{tabular}{|c|c|c|c|c|c|c|c|}
\hline$\overline{\text { Variable }}$ & Group & & Mean & Std.Dev. & Min & $\operatorname{Max}$ & Observation \\
\hline \multirow[t]{5}{*}{ Debt to Sales } & overall & & 156.95 & 498.40 & 0.00 & 11199.52 & $\mathrm{~N}=4704$ \\
\hline & between & sector-country & & 289.27 & 0.00 & 2392.89 & $\mathrm{n}=92$ \\
\hline & within & sector-country & & 427.83 & -2229.06 & 8963.58 & $\mathrm{~T}=51.13$ \\
\hline & between & country & & 134.06 & 50.07 & 678.79 & $\mathrm{n}=18$ \\
\hline & within & country & & 485.95 & -515.19 & 10677.68 & $\mathrm{~T}=261.33$ \\
\hline Variable & Group & & Mean & Std.Dev. & Min & $\operatorname{Max}$ & Observation \\
\hline \multirow[t]{5}{*}{ Debt to Assets } & overall & & 55.03 & 356.50 & 0.00 & 6652.25 & $\mathrm{~N}=4704$ \\
\hline & between & sector-country & & 175.60 & 0.00 & 1703.13 & $\mathrm{n}=92$ \\
\hline & within & sector-country & & 285.56 & -1619.88 & 5004.15 & $\mathrm{~T}=51.13$ \\
\hline & between & country & & 89.93 & 17.56 & 406.17 & $\mathrm{n}=18$ \\
\hline & within & country & & 340.93 & -335.90 & 6301.11 & T-bar $=261.33$ \\
\hline Variable & Group & & Mean & Std.Dev. & Min & $\operatorname{Max}$ & Observation \\
\hline \multirow[t]{5}{*}{ EPL Overall } & overall & & 1.97 & 0.97 & 0.21 & 3.67 & $\mathrm{~N}=6185$ \\
\hline & between & sector-country & & 0.90 & 0.21 & 3.49 & $\mathrm{n}=101$ \\
\hline & within & sector-country & & 0.30 & 0.97 & 2.79 & T-bar $=61.24$ \\
\hline & between & country & & 0.93 & 0.21 & 3.49 & $\mathrm{n}=18$ \\
\hline & within & country & & 0.30 & 0.97 & 2.79 & T-bar $=343.61$ \\
\hline
\end{tabular}


Table A.2: Employent elasticities

\begin{tabular}{lccccc}
\hline \multicolumn{1}{c}{ Country } & Mean & Std & Min & Max & Number of observations \\
& & & & & \\
Australia & 0.17 & 0.41 & -1.40 & 1.17 & 474 \\
Austria & 0.31 & 0.43 & -0.72 & 3.18 & 395 \\
Belgium & 0.09 & 0.22 & -0.78 & 0.80 & 518 \\
Canada & -0.49 & 1.39 & -5.22 & 2.19 & 90 \\
Denmark & 0.03 & 0.12 & -0.26 & 0.36 & 348 \\
Finland & 0.18 & 0.41 & -1.18 & 2.56 & 708 \\
France & 0.17 & 0.29 & -0.40 & 1.03 & 348 \\
Germany & 0.09 & 0.13 & -0.20 & 0.42 & 324 \\
Greece & 0.03 & 0.18 & -0.43 & 0.40 & 108 \\
Ireland & 0.10 & 0.27 & -0.27 & 0.92 & 108 \\
Italy & 0.11 & 0.32 & -0.88 & 1.08 & 564 \\
Netherlands & 0.08 & 0.47 & -0.87 & 2.33 & 420 \\
Norway & 0.05 & 0.23 & -0.57 & 0.76 & 228 \\
Portugal & 0.11 & 0.36 & -0.79 & 1.23 & 228 \\
Spain & 0.21 & 0.45 & -0.57 & 2.94 & 228 \\
Sweden & -0.03 & 0.54 & -1.17 & 2.65 & 138 \\
US & 0.22 & 0.24 & -0.24 & 1.09 & 890 \\
\hline \hline
\end{tabular}


Table A.3: Sectors with leverage in top $40 \%$ of the distribution

\begin{tabular}{|c|c|c|}
\hline country & sector & $\begin{array}{l}\text { highly leveraged (more than } 2 / 3 \text { of US value) } \\
\text { (more than } 2 / 3 \text { of US value) }\end{array}$ \\
\hline Australia & $\begin{array}{l}\text { construction } \\
\text { financial } \\
\text { industrial }\end{array}$ & yes \\
\hline Canada & construction & yes \\
\hline Finland & financial & yes \\
\hline France & $\begin{array}{l}\text { construction } \\
\text { financial }\end{array}$ & $\begin{array}{l}\text { yes } \\
\text { yes }\end{array}$ \\
\hline Germany & financial & \\
\hline $\begin{array}{l}\text { Italy } \\
\text { Netherlands }\end{array}$ & $\begin{array}{l}\text { financial } \\
\text { financial }\end{array}$ & yes \\
\hline Norway & $\begin{array}{l}\text { construction } \\
\text { financial } \\
\text { industrial }\end{array}$ & $\begin{array}{l}\text { yes } \\
\text { yes } \\
\text { yes }\end{array}$ \\
\hline Portugal & financial & yes \\
\hline Spain & $\begin{array}{l}\text { construction } \\
\text { financial }\end{array}$ & yes \\
\hline United Kingdom & financial & yes \\
\hline United States & $\begin{array}{l}\text { construction } \\
\text { financial } \\
\text { industrial }\end{array}$ & \\
\hline
\end{tabular}


Table A.4: Two-Stages Least Squares - Instrument: Dummy for young management

First Stage

\begin{tabular}{lcc}
\hline \hline & $(1)$ & $(2)$ \\
VARIABLES & $\mathrm{DS}^{*} \mathrm{FC}^{*} \Delta y$ & $\mathrm{DA}^{*} \mathrm{FC}^{*} \Delta y$ \\
\hline$\Delta y$ & $90.7132^{* * *}$ & $0.124^{* *}$ \\
& $(2.765)$ & $(0.053)$ \\
$\mathrm{FC}^{*} \Delta y$ & $-137.2255^{* * *}$ & $54.0027^{* * *}$ \\
& $(13.452)$ & $(1.099)$ \\
young $* \mathrm{FC} * \Delta y$ & $1,135.0750^{* * *}$ & $-161.4754^{* * *}$ \\
& $(70.217)$ & $(5.739)$ \\
Constant & -0.0024 & -0.0009 \\
& $(0.007)$ & $(0.001)$ \\
Observations & 1,474 & 1,474 \\
R-squared & 0.482 & 0.929 \\
\hline \hline
\end{tabular}

\begin{tabular}{lcc}
\multicolumn{3}{c}{ Second Stage } \\
\hline \hline & $(1)$ & $(2)$ \\
VARIABLES & $\Delta e$ & $\Delta e$ \\
$\Delta y$ & $0.124^{* *}$ & $0.098^{* *}$ \\
& $(0.053)$ & $(0.040)$ \\
$\mathrm{FC} * \Delta y$ & 2.082 & -2.684 \\
& $(4.201)$ & $(6.559)$ \\
$\mathrm{DS} * \mathrm{FC} * \Delta y$ & -0.022 & \\
& $(0.055)$ & \\
$\mathrm{DA} * \mathrm{FC} * \Delta y$ & & 0.131 \\
& & $(0.277)$ \\
low EPL $* \Delta y$ & -0.042 & -0.042 \\
& $(0.050)$ & $(0.050)$ \\
$\mathrm{STW} * \Delta y$ & 9.376 & -1.179 \\
& $(16.995)$ & $(36.198)$ \\
Constant & $0.009 * *$ & 0.012 \\
& $(0.004)$ & $(0.008)$
\end{tabular}

\begin{tabular}{lrr} 
Observations & 1,474 & 1,474 \\
R-squared & -0.135 & 0.198 \\
\hline \hline Standard errors in parentheses \\
${ }_{* * *} \mathrm{p}<0.01,{ }^{* *} \mathrm{p}<0.05,{ }^{*} \mathrm{p}<0.1$
\end{tabular}

